MAPPING THE END OF EMPIRE 



\section{Mapping the End of Empire}

AMERICAN AND BRITISH STRATEGIC VISIONS IN THE POSTWAR WORLD

Aiyaz Husain

II Harvard University Press

Cambridge, Massachusetts

London, England

2014 
Copyright () 2014 by the President and Fellows of Harvard College All rights reserved

Printed in the United States of America

\section{Library of Congress Cataloging-in-Publication Data}

Husain, Aiyaz, 1977-

Mapping the end of empire : American and British strategic visions in the postwar world / Aiyaz Husain.

pages $\mathrm{cm}$

Includes bibliographical references and index.

ISBN 978-0-674-72888-2 (alk.paper)

1. Decolonization-Middle East. 2. Decolonization-South Asia. 3. Geographical perception-Middle East. 4. Geographical perception-South Asia. 5. PalestineHistory-1917-1948. 6. Jammu and Kashmir (India)—History—20th century.

7. Great Britain—Foreign relations-1945-1964. 8. United States-Foreign relations-1945-1953. I. Title.

DS63.18.H86 2014

956.04—dc23 2013037069 
For my parents 
